$\begin{array}{ll} & \text { Etnográfica } \\ \text { etnográfica } & \text { Revista do Centro em Rede de Investigação em }\end{array}$

Antropologia

vol. 20 (3) | 2016

Vol. 20 (3)

\title{
The primatologist as social actor
}

o primatólogo como ator social

\section{Catherine M. Hill and Matthew R. McLennan}

\section{(2) OpenEdition}

Journals

\section{Electronic version}

URL: https://journals.openedition.org/etnografica/4771

DOI: 10.4000/etnografica.4771

ISSN: 2182-2891

\section{Publisher}

Centro em Rede de Investigação em Antropologia

\section{Printed version}

Date of publication: 1 October 2016

Number of pages: 668-671

ISSN: 0873-6561

\section{Electronic reference}

Catherine M. Hill and Matthew R. McLennan, "The primatologist as social actor", Etnográfica [Online], vol. 20 (3) | 2016, Online since 28 November 2016, connection on 11 February 2022. URL: http:// journals.openedition.org/etnografica/4771; DOI: https://doi.org/10.4000/etnografica.4771

\section{(c) (i) (9)}

Etnográfica is licensed under a Creative Commons Attribution-NonCommercial 4.0 International License. 


\title{
The primatologist as social actor
}

\section{Catherine M. Hill and Matthew R. McLennan}

\begin{abstract}
This communication explores the role of primatologists conducting fieldwork in human-impacted habitats and how they can become part of a complex social and political landscape. Cláudia Sousa was interested in how to avoid or mitigate negative interactions involving local populations, researchers and other stakeholders in biodiversity conservation programmes.

KEYWORDS: fieldwork, chimpanzees, conflict, NGOs, conservation, primatology.

O primatólogo como ator social - Esta comunicação explora o papel dos primatólogos que conduzem trabalho de campo em habitats com impacto humano e como podem tornar-se parte de panoramas políticos e sociais complexos. Cláudia Sousa estava interessada em analisar como evitar ou mitigar as interações negativas envolvendo as populações, os investigadores e outras partes interessadas em programas de conservação da biodiversidade.
\end{abstract}

PALAVRAS-CHAVE: trabalho de campo, chimpanzés, conflito, ONG, conservação, primatologia.

HILL, Catherine M. (cmhill@brookes.ac.uk) - Anthropology Centre for Conservation, Environment and Development, Oxford Brookes University, UK.

McLENNAN, Matthew R. (mmclennan@brookes.ac.uk) - Anthropology Centre for Conservation, Environment and Development, Oxford Brookes University, UK.

\section{PRIMATOLOGY FIELDWORK IS INCREASINGLY CARRIED OUT WITH} permission and support from local people and district and national level government personnel. This requires researchers to develop relationships with local residents and officials particularly. Consequently, it is impossible to do such fieldwork without influencing the attitudes, behaviour and decision-making of these individuals, at least to some degree (Wilson 1992; McLennan and Hill 2013). We use the second author's (McLennan's) fieldwork experience as a researcher examining chimpanzee (Pan troglodytes schweinfurthii) ecology in a human-dominated habitat in Uganda to explore the role of the primatologist as a social actor, i. e. the influence an outsider's arrival and subsequent research activities can have on social processes and political dynamics locally, affecting what people say or do.

McLennan's fieldwork took place in Bulindi, Northern Hoima District, in Western Uganda. Bulindi lies between two large government-controlled, forest reserves, Budongo and Bugoma. Both forests are home to important chimpanzee populations. The intervening area is densely cultivated, with 
small forest patches on non-government land also occupied by chimpanzees (McLennan 2008).

Prior to the onset of fieldwork we were aware that unprotected forest patches in the region were under threat from agricultural expansion, especially for cash cropping. However, we did not know that these same forest patches were being targeted for timber production or the importance of this to local livelihood strategies or local government coffers. This only became clear as fieldwork progressed. Local concerns and anxieties about land tenure and individual householders' legal rights to land also only came to light through the process of fieldwork. Few households had registered their land holdings, yet the 1998 Uganda Land Act recognises customary land ownership, meaning households are entitled to claim legal ownership of natural forest on non-registered land. Officials might assume that this research would draw attention to chimpanzees locally, which in turn could attract the attention of conservation agencies and other interested parties. Consequently, his arrival very likely was perceived as threatening certain interests of locally powerful households and officials.

Unbeknown to us, even before McLennan began his research, chimpanzees were already at the centre of a local dispute. Several years earlier, Peter (pseudonym), a member of a powerful local family, tried to enlist support for a proposed ecotourism project at Bulindi. McLennan met Peter during the early stages of his fieldwork, but only learned much later on that Peter's idea had met with very strong opposition within the local community, because people feared it would result in formal protection of local forest patches (for the chimpanzees) and people would be forced off their land and/or denied access to forest resources. Residents were unconvinced that McLennan's activities were independent of Peter's original ecotourism proposal, thus were concerned his research might impact their access to important resources. Unfortunately, further events strengthened this view.

McLennan held a public meeting to update people on his research progress. A local conservation NGO used the occasion to announce their mandate to implement chimpanzee and forest conservation locally, with a renewed emphasis on ecotourism at Bulindi, independent of Peter's original proposal. They also claimed they were collaborating with the chimpanzee researchers, but this information was conveyed in Lunyoro, so McLennan remained unaware of this crucial piece of information. The NGO then made an announcement on local radio of their, as yet unfunded, conservation and ecotourism programme. The first McLennan knew of this apparent collaboration was via the radio broadcast! And three days after the broadcast loggers arrived at Bulindi and began felling trees in the chimpanzees' core area.

The researcher's presence, alongside the activities of the conservation NGO, very likely, precipitated increased rates of habitat degradation as people raced 
to realise a profit from local timber resources, apparently believing their access to forest resources (including land) might be reduced in the future. So we see the effects of "researcher influence" locally in increased rates of tree felling. But it did not end there.

Following an attack locally on a young child by a chimpanzee, McLennan felt compelled to intervene. He engaged in discussions with local dignitaries and forest owners about the effects of the forest degradation on chimpanzee behaviour and the likely risks to people of it continued at such a pace. Additionally, he contacted a senior forestry official. Armed forest guards came to Bulindi and arrested two unlicensed, non-local, timber cutters, and confiscated a chain saw (it is illegal to cut timber without a licence). Mechanised timber felling stopped but this respite was short-lived.

What was the outcome of this intervention for McLennan's relationships locally? At the insistence of local people, his involvement in community affairs intensified, particularly issues involving forest, or wildlife, but increasingly this extended to matters unrelated to his research. McLennan's role had become blurred - he was a researcher but was increasingly required to behave as a conservationist. Meanwhile, local people were now more confident about his role and his intent - as a conservationist. As a researcher he was unfamiliar to them and a potential threat. As a conservationist he had a role they recognised and understood: that of protecting forests and chimpanzees. Through these social processes and events McLennan become increasingly involved in local socio-political systems, i.e., he became a key actor, influencing the ecological, conservation and social landscape he had gone to study.

This "researcher influence" has long been recognised by social anthropologists in relation to the human groups they study (Kloos 1969), but is rarely, if ever, acknowledged in primatology. We suggest this is an important omission that requires further consideration, particularly with regards to research directed towards issues of relevance to conservation. Consequently, as primatologists we should reflect on, and take into account, our possible role in local social and political dynamics, because these may have a direct impact on our research and conservation activities, as well as unanticipated impacts on the animals or habitats we study and work to protect. 


\section{REFERENCES}

KLOOS, Peter, 1969, "Role conflicts in social fieldwork”, Current Anthropology, 10 (5): 509-523 .

McLENNAN, Matthew R., 2008, "Beleaguered chimpanzees in the agricultural district of Hoima, Western Uganda", Primate Conservation, 23: 45-54.

McLENNAN, Matthew R., and Catherine M. HILL, 2013, "Ethical issues in the study and conservation of an African Great Ape in an unprotected, human-dominated landscape in Western Uganda", in Jeremy V. MacClancy and Agustin Fuentes (eds.), Fieldwork Ethics in Biological Anthropology. Oxford, Berghahn Press, 42-66.

WILSON, Ken, 1992, "Thinking about the ethics of fieldwork", in Stephen Devereux and John Hoddinott (eds.), Fieldwork in Developing Countries. London, Harvester Wheatsheaf, 179-199. 